University of Nebraska - Lincoln

DigitalCommons@University of Nebraska - Lincoln

Faculty Publications: Department of

Entomology

Entomology, Department of

$5-2008$

Development of methods to evaluate susceptibility of soybean aphid to imidacloprid and thiamethoxam at lethal and sublethal concentrations

\author{
Leonardo C. Magalhaes \\ University of Nebraska-Lincoln \\ Thomas E. Hunt \\ University of Nebraska, Haskell Agricultural Laboratory, Concord, NE, thunt2@unl.edu \\ Blair D. Siegfried \\ University of Nebraska-Lincoln, bsiegfried1@ufl.edu
}

Follow this and additional works at: https://digitalcommons.unl.edu/entomologyfacpub

Part of the Entomology Commons

Magalhaes, Leonardo C.; Hunt, Thomas E.; and Siegfried, Blair D., "Development of methods to evaluate susceptibility of soybean aphid to imidacloprid and thiamethoxam at lethal and sublethal concentrations" (2008). Faculty Publications: Department of Entomology. 151.

https://digitalcommons.unl.edu/entomologyfacpub/151

This Article is brought to you for free and open access by the Entomology, Department of at DigitalCommons@University of Nebraska - Lincoln. It has been accepted for inclusion in Faculty Publications: Department of Entomology by an authorized administrator of DigitalCommons@University of Nebraska - Lincoln. 
Published in Entomologia Experimentalis et Applicata 128:2 (2008), pp. 330-336; doi 10.1111/j.1570-7458.2008.00718.x Copyright (C) 2008 Leonardo C. Magalhaes, Thomas E. Hunt, and Blair D. Siegfried. Journal compilation (C) 2008 The Netherlands Entomological Society; published by John Wiley \& Sons. Used by permission. http://www.interscience.wiley.com/jpages/0013-8703

\title{
Development of methods to evaluate susceptibility of soybean aphid to imidacloprid and thiamethoxam at lethal and sublethal concentrations
}

\author{
Leonardo C. Magalhaes, ${ }^{1}$ Thomas E. Hunt, ${ }^{2}$ and Blair D. Siegfried ${ }^{1}$ \\ ${ }^{1}$ Department of Entomology, University of Nebraska, 202 Plant Industry Building, Lincoln, NE 68583-0816, USA, and \\ ${ }^{2}$ University of Nebraska, Haskell Agricultural Laboratory, 57905866 Road, Concord, NE 68728-2828, USA \\ Corresponding author - B. D. Siegfried, Department of Entomology, 202 Plant Industry Building, \\ University of Nebraska-Lincoln, Lincoln, NE 68583-0816, USA. Email bsiegfried1@unl.edu
}

\begin{abstract}
The soybean aphid, Aphis glycines Matsumura (Homoptera: Aphididae), is a recent introduction (2000) from Asia and has become a serious soybean [Glycine max (L.) Merr. (Fabaceae)] pest in North America. Seed treatments using the neonicotinoid insecticides, imidacloprid and thiamethoxam, have been suggested as a method of control, and the use of these insecticides is becoming widespread. As a consequence, there is increased potential to select for resistance to these compounds. In the case of soybean aphids, baseline susceptibility to neonicotinoid insecticides and standardized methods for bioassay are lacking. A bioassay technique that uses excised soybean leaves immersed in an insecticide solution was developed to determine systemic insecticidal activity at lethal and sublethal concentrations. Mortality and population growth inhibition were evaluated after 7 days. Life table parameters were calculated by exposing 1-day-old aphids to three concentrations of thiamethoxam. Aphid mortality and nymph production were recorded daily until the entire cohort collapsed. Soybean aphid age-specific survivorship, fecundity, net reproductive rate, longevity, intrinsic rate of increase, discrete daily growth rate, and life expectancy were all significantly reduced at higher thiamethoxam concentrations. Soybean aphid response to both insecticides was similar, and both compounds were very toxic with $\mathrm{LC}_{50} \mathrm{~s}$ of 31.3 and $16.9 \mathrm{ng} \mathrm{ml}^{-1}$ and $\mathrm{EC}_{50} \mathrm{~s}$ of 6.3 and $5.4 \mathrm{ng} \mathrm{ml}^{-1}$ for imidacloprid and thiamethoxam, respectively. These results indicate that the methods developed in this study had negligible impact on the life table estimates measured and can be used to develop a baseline of susceptibility as a benchmark for subsequent resistance monitoring. Given the rapid and widespread adoption of this new insecticide class, vigilant monitoring for changes in susceptibility will be essential to its long-term sustainability.
\end{abstract}

Keywords: seed treatment, neonicotinoid, bioassay, life table, Homoptera, Aphididae, Aphis glycines, Glycine max

\section{Introduction}

After its introduction to North America, the soybean aphid, Aphis glycines Matsumura (Homoptera: Aphididae), has spread rapidly and poses a serious threat to soybean [Glycine max (L.) Merr. (Fabaceae)] production in North America (Venette \& Ragsdale, 2004). Key natural enemies found in North America, such as the coccinellid Harmonia axyridis (Pallas) (Coleoptera: Coccinellidae) and the minute pirate bug Orius insidious (Say) (Heteroptera: Anthocoridae) (Rutledge et al., 2004), do not reliably reduce aphid populations in North Amer- ica, and outbreaks and soybean yield losses occur regularly (Ostlie, 2001). Furthermore, soybean aphid populations can change quickly over time, doubling in less than 2 days under ideal conditions (McCornack et al., 2004). Therefore, population suppression by natural enemies has been inconsistent, and various approaches that do not rely solely on natural enemy control are required.

Several different non-chemical approaches to managing soybean aphids have been examined, such as the use of parasitoids imported from Asia (Heimpel et al., 2004) or introduction of resistant varieties (Li et al., 2004; Mensah et al., 2005). However, these control methods may 
take several years to be effective, and as a consequence, soybean farmers rely mainly on chemical control.

In several areas of the midwestern USA, soybean aphid has been responsible for the first ever insecticide application to soybean fields (Rutledge \& O'Neil, 2005), and there is an urgent need to develop reliable and sustainable soybean aphid management strategies. A single foliar application of $\lambda$-cyhalothrin or chlorpyrifos at R2 to R3 stages of plant development has been shown to prevent yield losses (Myers et al., 2005a). However, soybean aphid populations are affected by many factors, and regional and seasonal variation is common. Therefore, a second application is sometimes required to keep aphid densities below economic threshold levels. In addition, foliar application of broad spectrum insecticides may reduce natural enemies (Galvan et al., 2005) contributing to pest resurgence. In contrast, systemic insecticides applied as seed treatment may offer increased selectivity over foliar-applied insecticides (Krauter et al., 2001; Albajes et al., 2003) and may provide longer plant protection (Nault et al., 2004) than foliar-applied insecticides.

Neonicotinoid insecticides are commonly used as systemic insecticides and are highly effective in controlling piercing-sucking insects (Tomizawa \& Casida, 2005). Similar to nicotine, neonicotinoids act as agonists at the postsynaptic acetylcholine receptor (Tomizawa \& Casida, 2003). Imidacloprid and thiamethoxam are two neonicotinoids that have been utilized as seed treatments to reduce soybean aphid densities. Because the use of these insecticides is becoming more widespread, particularly as seed treatments, there is increased potential for selection of target pests for resistance. For this reason, baseline susceptibility of target pest species should be established to provide a mechanism for early detection of resistance development. Additionally, because these insecticides are used as seed treatments, less insecticide is available as the plant grows, and the insect pest may then become exposed to sublethal concentrations. Most toxicological studies focus on dose/response estimates to establish lethal doses or concentrations, but a toxicant may have broader, more subtle effects (Stark \& Banks, 2003). Moreover, a reduction in population growth as a result of exposure to sublethal concentrations may provide more time for natural enemies to affect population dynamics (Satoh et al., 1995).

In the case of soybean aphids, methods for exposing aphids to neonicotinoid insecticides are lacking such that measurement of baseline susceptibility or determining effects of sublethal exposure have not been possible. This study was designed to provide information on soybean aphid susceptibility to two neonicotinoid insecticides, imidacloprid and thiamethoxam. Additionally, the impact of thiamethoxam on soybean aphid lifehistory characteristics at different concentrations was determined. Importantly, the methodology developed provides a basis to establish baseline susceptibility from geographically distinct populations that can be used to detect future changes in susceptibility that may occur in response to increased selective pressures.

\section{Materials and methods}

\section{Soybean aphid and plant material}

A soybean aphid laboratory colony was initiated in July 2005 from individuals collected from infested fields near the University of Nebraska Northeast Research and Extension Center Haskell Agricultural Laboratory (Dixon Co., NE, USA; $42^{\circ} 23^{\prime} \mathrm{N}, 96^{\circ} 57^{\prime} \mathrm{W}$ ). The colony was maintained on a continuous supply of soybean seedlings (V4V6 stages) (Syngenta S23-Z3) (Research Triangle Park, NC, USA). New plants were provided weekly to the colony and aphids were transferred by placing infested leaves on uninfested plants. The colony was maintained at $25 \pm 2{ }^{\circ} \mathrm{C}, 75 \pm 5 \%$ r.h., and a photoperiod of L16:D8 $\mathrm{h}$ in a plant growth chamber.

Four seeds were planted in $15 \mathrm{~cm}$ diameter $\times 17 \mathrm{~cm}$ deep pots in a soil mix containing sand soil-peat-perlite in a 2:1:3:3 ratio. After germination, the seedlings were thinned to three to reduce competition. Plants were watered daily and fertilized weekly with a soluble fertilizer (20N:10P:20K). Plants were grown in greenhouses at $25 \pm 7^{\circ} \mathrm{C}$ under 400 -W high-intensity discharge lamps with an L16:D8 h photoperiod.

\section{Insecticides}

Technical grade imidacloprid and thiamethoxam were purchased from Chem Service (West Chester, PA, USA) and maintained at $-20^{\circ} \mathrm{C}$. Insecticidal stock solutions were prepared in acetone and further diluted to each concentration in double distilled water for use in systemic bioassays. Acetone concentrations at the highest insecticidal concentrations were less than $0.01 \%$ and did not significantly affect mortality.

\section{Systemic bioassay}

A systemic bioassay was developed that allowed excised soybean leaves immersed in insecticide solution to take up the insecticide through their petioles. Similar bioassays have been used to measure the susceptibility of sucking insect pests to systemic insecticides in cotton (Nauen et al., 2002; Prabhaker et al., 2005), cabbage (Nauen \& Elbert, 1997), and citrus (Prabhaker et al., 2006).

The cut petioles of excised soybean leaves were immersed in insecticide solution with different concentrations of imidacloprid or thiamethoxam. The control leaves had their petioles immersed in water alone and there were at least four replicates and five different con- 
centrations per insecticide bioassay. To reduce soybean leaf variation, only the first and second trifoliate from healthy V4 stage soybean seedlings were used. The petioles were kept aphid-free overnight (approximately $12 \mathrm{~h}$ ) to allow insecticide uptake and recovery of leaf turgidity.

An opaque, plastic tray (CD International, Pitman, NJ, USA) containing eight square cells $(10 \mathrm{~cm}$ per side $\times 8 \mathrm{~cm}$ in depth) was used to keep the aphids separated in each treatment. To avoid aphid escapes, each cell was sealed with a porous transparent plastic lid (CD International). Five milliliters of each concentration was dispensed into a glass tube $(1 \mathrm{~cm}$ in diameter $\times 5 \mathrm{~cm}$ depth) and the tube was attached to the tray with adhesive tape.

Thirty aphids (including all developmental stages) were then transferred to the leaves using a fine camel hair paintbrush. After 7 days, the dead and living aphids were counted. Aphids were considered dead when they did not respond to prodding. The trays were held in a growth chamber at $25^{\circ} \mathrm{C}$, L16:D8 h photoperiod, and $75 \pm 5 \%$ r.h. $\mathrm{LC}_{50}$ values were calculated based on aphid mortality and $\mathrm{EC}_{50}$ values were calculated based on the percentage reduction in living aphids relative to controls.

\section{Sublethal effects}

Only thiamethoxam was tested for sublethal effects, and concentrations were chosen based on preliminary response curves and corresponded to the $\mathrm{LC}_{25}, \mathrm{LC}_{50}$, and $\mathrm{LC}_{75}$. In order to synchronize nymph production, several apterous adults were transferred to excised leaves immersed in water. Twenty-four hours later, a cohort of 25 1-day-old aphids were selected and then carefully transferred to the upper side of the leaves using a fine camel hair paintbrush. Leaves and insecticide solutions were replaced at 7-day intervals to maintain an adequate food source for the aphids. The number of dead aphids, living aphids, and nymphs produced were recorded daily until the initial cohort of 25 aphids had died. Aphids were considered dead when they did not respond to prodding. Neonate nymphs produced were removed daily to avoid miscalculations. The experiment was repeated four times. The trays were maintained in a walk-in growth chamber at $26 \pm 2{ }^{\circ} \mathrm{C}, \mathrm{L} 16$ :D8 $\mathrm{h}$ photoperiod, and $75 \pm 5 \%$ r.h.

\section{Calculation of life table parameters}

Age-specific survivorship $\left(1_{x}\right)$ and age-specific fecundity $\left(\mathrm{m}_{\mathrm{x}}\right)$ (Gotelli, 2001) were calculated for each concentration. Age-specific survivorship was calculated based on the formula $l_{x}=S_{x} / S_{0}$, where $x$ is the age interval (days), $S_{x}$ is the number of survivors at age $x$ and $S_{0}$ is the size of the original cohort. Age-specific fecundity $\left(\mathrm{m}_{\mathrm{x}}\right)$ is the average number of nymphs produced at a specific age $\mathrm{x}$ by all aphids living at that age. However, $\mathrm{m}_{\mathrm{x}}$ was trans- formed to cumulative fecundity to facilitate graphical visualization and interpretation of the difference among treatments. Cumulative fecundity is the average number of nymphs born per adult at a specific age $\mathrm{x}$, plus the nymphs born in previous days. Other life table parameters, such as the intrinsic rate of increase (r), adapted from the Euler equation $\Sigma \mathrm{e}^{-\mathrm{rx}} 1_{\mathrm{x}} \mathrm{m}_{\mathrm{x}}=1$, the net reproductive rate, $R_{0}=\Sigma 1_{x} m_{x^{\prime}}$ generation time or number of days to reproductive maturity, $G=\Sigma 1_{x} m_{x} x / R_{0}$, doubling time, $t_{d}=\ln (2) / r$, finite rate of increase $(\lambda), r=\ln (\lambda)$, and life expectancy, $\mathrm{e}_{0}=\Sigma 1_{\mathrm{x}+1} 1_{\mathrm{x}}^{-1}$ were also estimated.

\section{Statistical analysis}

The mortality data were analyzed by probit analysis (Finney, 1971) using POLO-PC (LeOra Software, 1987) and corrected using Abbott's formula (Abbott, 1925). Nymphs produced were transformed to percentage population growth inhibition relative to controls. These data were then analyzed by non-linear regression (PROC NLIN; SAS Institute, 2002). $\mathrm{LC}_{50}, \mathrm{LC}_{90}$, and $\mathrm{EC}_{50}$ values were considered significantly different when confidence limits and intervals did not overlap (Prabhaker et al., 2005).

To generate standard errors for each parameter, the population statistics $r, R_{0}, G, t_{d}, \lambda$, and $e_{0}$ were estimated for each cohort (4). Cohorts that did not produce nymphs were excluded from the analysis of reproductive parameters $r, G, t_{d}$, and $\lambda$. The parameters were analyzed by one-way analysis of variance (ANOVA) using the mixed procedure (PROC MIXED; SAS Institute, 2002). Once the treatment effect was significantly different $(P<0.05)$ by ANOVA, then Fisher's protected least significant difference was performed to identify differences among treatment means (PROC MIXED; SAS Institute, 2002). PROC LIFETEST (SAS Institute, 2002) using Kaplin-Meier estimator for survival was used to calculate survivorship curves as a function of days. Significant differences among survivorship curves were determined by Wilcoxon's $\chi^{2}$-test of equality. Pearson's $\chi^{2}$ analysis was used to compare the different cumulative fecundity dose curves with control.

\section{Results}

\section{Bioassays}

Soybean aphids were highly susceptible to both neonicotinoid insecticides based on responses to treated soybean foliage with $\mathrm{LC}_{50} \mathrm{~s}$ of 31.3 and $16.9 \mathrm{ng} \mathrm{ml}^{-1}$ for imidacloprid and thiamethoxam, respectively (Table 1 ). Both compounds also caused significant sublethal effects based on calculated $\mathrm{EC}_{50} \mathrm{~s}$ of 6.3 and $5.4 \mathrm{ng} \mathrm{ml}^{-1}$ imidacloprid and thiamethoxam, respectively (Table 1). These results suggest that soybean aphids respond at concentrations well below those that cause mortality. 
Table 1. Aphis glycines susceptibility exposed to imidacloprid and thiamethoxam systemic bioassays as measured by growth inhibition and mortality

\begin{tabular}{lcccccc}
\hline Insecticide & No. & Slope $\pm \mathrm{SE}$ & $\mathrm{LC}_{50} \mathrm{ng} \mathrm{ml}^{-1}(95 \% \mathrm{CL})$ & $\mathrm{LC}_{90} \mathrm{ng} \mathrm{ml}^{-1}(95 \% \mathrm{CL})$ & $\mathrm{X}^{2}(\mathrm{~d} . \mathrm{f})$. & $\mathrm{EC}_{50} \mathrm{ng} \mathrm{ml}^{-1}(95 \% \mathrm{CI})^{1}$ \\
\hline Imidacloprid & 3891 & $2.21 \pm 0.214$ & $31.29(21.75-41.95)$ & $118.87(84.04-203.1)$ & $7.15(5)$ & $6.29(4.85-8.12)$ \\
Thiamethoxam & 4349 & $3.12 \pm 0.373$ & $16.91(7.38-26.74)$ & $43.54(27.63-76.06)$ & $4.14(3)$ & $5.38(1.53-12.61)$ \\
\hline
\end{tabular}

${ }^{1}$ Concentration of imidacloprid and thiamethoxam that produces $50 \%$ population growth inhibition relative to untreated controls. Calculated by non-linear fitted probit model. CL, confidence limit; CI, confidence interval.

\section{Aphid net reproductive rate and longevity}

Consistent with the sublethal effects observed previously, thiamethoxam had a significant impact on soybean aphid net reproductive rate $\left(\mathrm{R}_{0}\right)$ and longevity especially at the highest concentration (Figures 1 and 2, respectively). At the lower concentrations, the number of nymphs produced per adult $\left(\mathrm{R}_{0}\right)$ was not significantly different from control $\left(P=0.5868\right.$ at the $\mathrm{LC}_{25}$ and $P=0.1410$ at the $\left.\mathrm{LC}_{50}\right)$. However, at $\mathrm{LC}_{75}$, significantly fewer nymphs were produced relative to the control treatment $(P=0.0096)$. In general, as the thiamethoxam concentration increased, the net reproductive rate decreased (Figure 1). A similar trend was observed for longevity with increasing thiamethoxam concentrations (Figure 2). Aphids not exposed to insecticide (control)

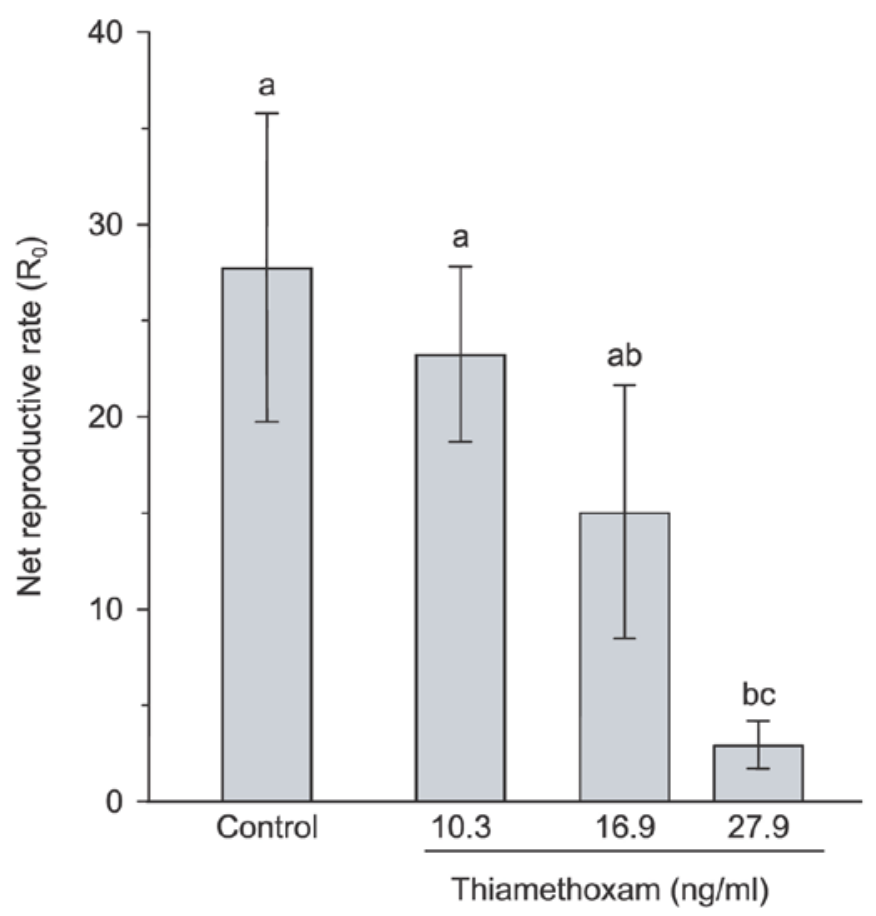

Figure 1. Fecundity (mean $\pm \mathrm{SE}$ ) of Aphis glycines (net reproductive rate or number of nymphs produced by each adult until the cohort had died) reared on thiamethoxam concentrations corresponding to the $\mathrm{LC}_{25}\left(10.3 \mathrm{ng} \mathrm{ml}^{-1}\right), \mathrm{LC}_{50}\left(16.9 \mathrm{ng} \mathrm{ml}^{-1}\right.$, and $\mathrm{LC}_{75}\left(27.9 \mathrm{ng} \mathrm{ml}^{-1}\right)$ compared to control. Bars capped with a different letter are significantly different (Fisher's protected least significant difference: $P<0.05 ; n=4)$. lived significantly longer $(P<0.0001)$ than aphids exposed to concentrations corresponding to the $\mathrm{LC}_{50}$ and $\mathrm{LC}_{75}$, although there was no significant difference between the control and $\mathrm{LC}_{25}$ treatment $(P=0.8566)$.

\section{Aphid survivorship and fecundity}

Age-specific survivorship was significantly reduced as the concentration of thiamethoxam increased (Figure 3). Thiamethoxam at the $\mathrm{LC}_{25}$ and $\mathrm{LC}_{50}$ did not significantly reduce soybean aphid survivorship $\left(x^{2}=5.159\right.$, d.f. $=2, P=0.0758)$, but the $L_{75}$ treatment survivorship was significantly reduced compared with control treatment $\left(X^{2}=48.2\right.$, d.f. $\left.=1, P<0.0001\right)$ (Figure 3). Sublethal concentrations of thiamethoxam caused a reduction in aphid fecundity with increasing concentrations (Figure 4). Aphids in the thiamethoxam $\mathrm{LC}_{25}$ treatment had a cumulative fecundity similar to control $\left(x^{2}=27.09\right.$, d.f. $=29, P=0.5671)$. However, both the $\mathrm{LC}_{50}$ and $\mathrm{LC}_{75}$ of thiamethoxam significantly reduced aphid fecundity $\left(X^{2}=17.09\right.$, d.f. $=8, P=0.0291$ and $\chi^{2}=20.32$, d.f. $=7$, $P=0.0049)$ after 9 and 8 days, respectively.

\section{Other population growth parameters}

In general, higher thiamethoxam concentrations caused greater impact on soybean aphid growth parameters (Table 2). With the exception of generation time $(F=0.45$, d.f. $=3, P=0.7201)$ and doubling time $(F=0.54$, d.f. $=3$, $P=0.6655)$, all parameters were significantly affected by thiamethoxam. Intrinsic rate of increase, discrete daily growth rate, and life expectancy were all significantly reduced.

\section{Discussion}

Although $\mathrm{LC}_{50}$ and $\mathrm{EC}_{50}$ values for thiamethoxam were not significantly different, thiamethoxam appeared to be slightly more toxic than imidacloprid. However, imidacloprid may have had a greater effect on Aphis glycines populations than thiamethoxam at lower concentrations based on the similar $\mathrm{EC}_{50}$ values. Additionally, thiamethoxam significantly affected soybean aphid life-history traits at lower concentrations. These results suggest that both compounds have lethal and sublethal effects that impact reproductive capacity and survivorship. 


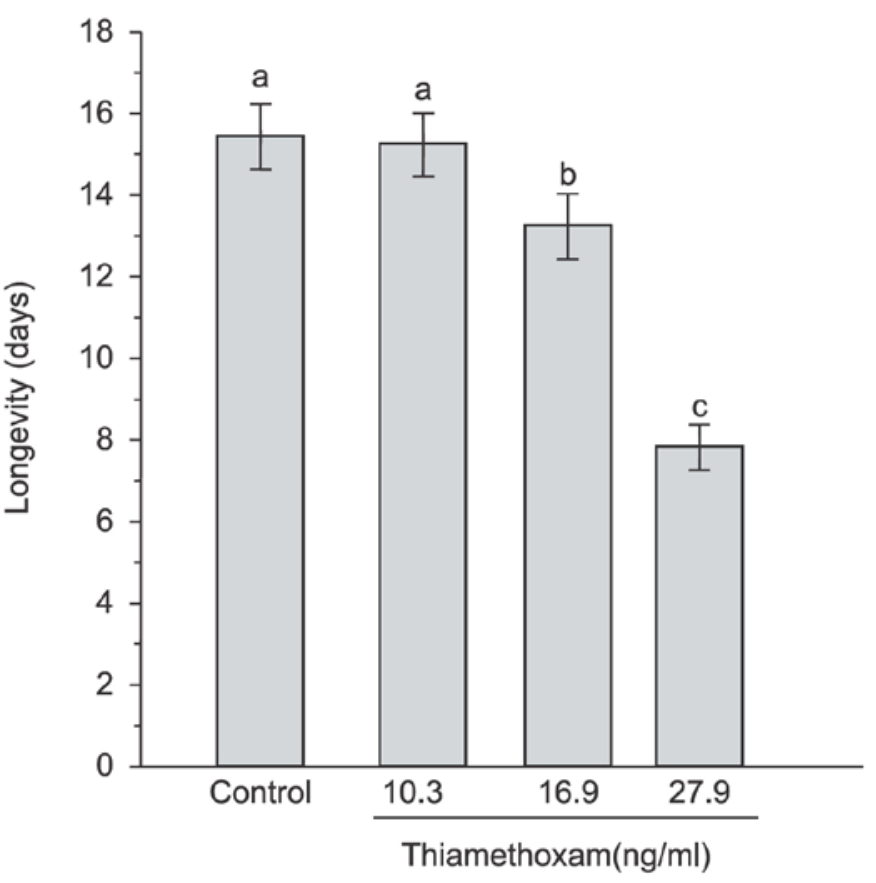

Figure 2. Longevity (mean $\pm \mathrm{SE}$ ) of Aphis glycines reared on thiamethoxam concentrations corresponding to the $\mathrm{LC}_{25}$ $\left(10.3 \mathrm{ng} \mathrm{ml}^{-1}\right), \quad \mathrm{LC}_{50}\left(16.9 \mathrm{ng} \mathrm{ml}^{-1}\right)$, and $\mathrm{LC}_{75}\left(27.9 \mathrm{ng} \mathrm{ml}^{-1}\right)$ compared to control. Bars capped with a different letter are significantly different (Fisher's protected least significant difference: $P<0.05: n=4$ ).

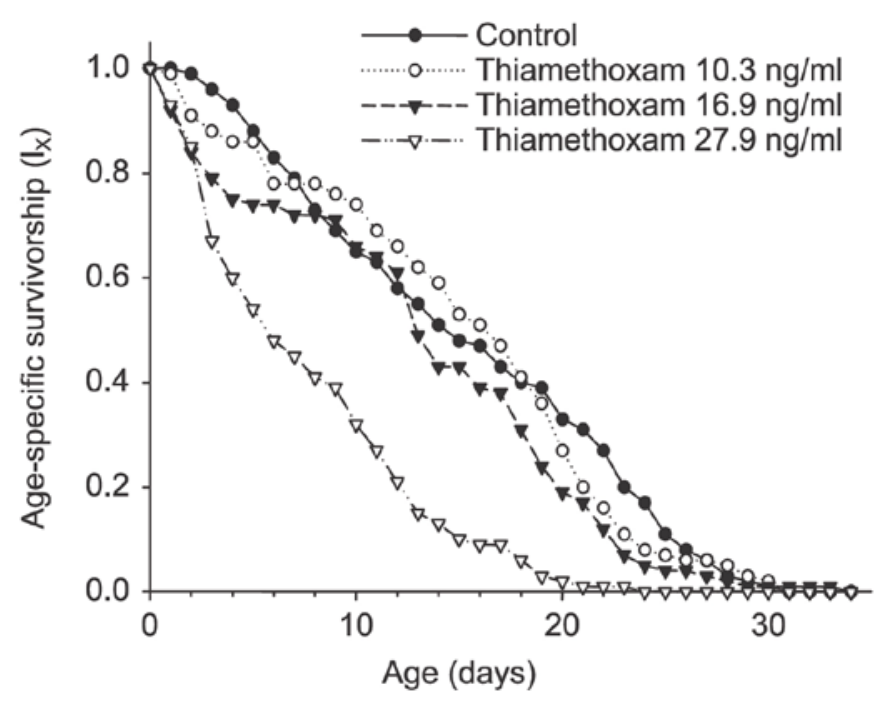

Figure 3. Age-specific survivorship of Aphis glycines reared on thiamethoxam concentrations corresponding to the $\mathrm{LC}_{25}$ $\left(10.3 \mathrm{ng} \mathrm{ml}^{-1}\right), \quad \mathrm{LC}_{50}\left(16.9 \mathrm{ng} \mathrm{ml}^{-1}\right)$, and $\mathrm{LC}_{75}\left(27.9 \mathrm{ng} \mathrm{ml}^{-1}\right)$ compared to control.
Such effects could be explained not only by direct insecticide toxicity but also by possible neonicotinoid antifeedant properties (Nauen, 1995; Devine et al., 1996; Nauen \& Elbert, 1997). Neonicotinoids have been shown to cause feeding inhibition in Myzus persicae (Sulzer) and Myzus nicotianae (Blackman) at concentrations in the parts per billion range (Devine et al., 1996).

The $\mathrm{LC}_{50} \mathrm{~s}$ obtained for soybean aphids for both compounds are in the range of reported for neonicotinoids using systemic bioassays for other plant-sucking insects. The $\mathrm{LC}_{50}$ for imidacloprid against the glassy-wing sharpshooter, Homalodisca coagulate (Say), ranged from 0.087 to $53.09 \mathrm{ng} \mathrm{ml}^{-1}$ (Prabhaker et al., 2006). However, $\mathrm{LC}_{50}$ values for Bemisia tabaci (Gennadius) were 264 and $108 \mu \mathrm{g} \mathrm{ml}^{-1}$ for imidacloprid and thiamethoxam, respectively (Prabhaker et al., 2005). Myzus nicotianae also exhibited generally higher $\mathrm{LC}_{50}$ values for imidacloprid [16 $\mu \mathrm{g} \mathrm{ml}^{-1}$ (Nauen \& Elbert, 1997)], which are much higher than values reported here for soybean aphids. In these other studies, mortality was evaluated after only 2 days, as opposed to the 7-day exposure in the present study, which may explain the generally higher soybean aphid susceptibility compared to Bemisia tabaci and Myzus nicotianae.

The methodology in the present study did not seem to affect soybean aphid performance because population growth estimates in the control treatment were similar to those previously reported for soybean aphids ( $\mathrm{Li}$ et al., 2004; McCornack et al., 2004; Myers et al., 2005b; Rutledge \& O'Neil, 2006) under both laboratory and field conditions. Our calculated net reproductive rate (Figure 1) was very close to that reported by Rutledge \& O'Neil (2006) and McCornack et al. (2004) but lower than the rate reported by Myers et al. (2005b). The longevity measured by Li et al. (2004) in the susceptible genotype (Pana) is almost identical to our estimates (Figure $2)$. The intrinsic rate of increase ( $r$ ) and discrete daily growth rate $(\lambda)$ obtained in this study (Table 2) presented intermediate values compared to those observed in these other studies (Myers et al., 2005b; Rutledge \& $\left.\mathrm{O}^{\prime} \mathrm{Neil}, 2006\right)$ and were surprisingly similar to those calculated by McCornack et al. (2004) for aphids reared at $30^{\circ} \mathrm{C}$. Other estimates for soybean aphid life table parameters were also within the range reported in previous studies.

Although we used excised leaves and a controlled environment in the bioassays, the life table estimates obtained were comparable with other studies. Most of the soybean aphid studies where life table parameters are reported are based on clip cages and/or whole plants (Li et al., 2004; McCornack et al., 2004; Rutledge \& O'Neil, 2006). However, it would be very difficult to obtain leaves with similar insecticide concentrations from plants originating from treated seeds. The methods used in the present study seem to have had negligible impact on the life table estimates measured. Leaves were re- 
Table 2. Comparison of life table estimates (means $\pm \mathrm{SE}$ ) for Aphis glycines reared on thiamethoxam concentrations corresponding to the $\mathrm{LC}_{25}\left(10.3 \mathrm{ng} \mathrm{ml}^{-1}\right), \mathrm{LC}_{50}\left(16.9 \mathrm{ng} \mathrm{ml}^{-1}\right)$, and $\mathrm{LC}_{75}\left(27.9 \mathrm{ng} \mathrm{ml}^{-1}\right)$

\begin{tabular}{|c|c|c|c|c|c|}
\hline \multirow[t]{2}{*}{ Parameter } & \multirow[t]{2}{*}{ Dimension } & \multirow[t]{2}{*}{ Control } & \multicolumn{3}{|l|}{ Thiamethoxam } \\
\hline & & & $\mathrm{LC}_{25}$ & $\mathrm{LC}_{50}$ & $\mathrm{LC}_{75}$ \\
\hline Intrinsic rate of increase $(\mathrm{r})^{1}$ & Aphids per day & $0.374 \pm 0.02 \mathrm{a}$ & $0.327 \pm 0.02 a$ & $0.242 \pm 0.06 \mathrm{ab}$ & $0.045 \pm 0.09 b c$ \\
\hline Doubling time $\left(t_{d}\right)^{1}$ & Days & $1.874 \pm 0.12$ & $2.148 \pm 0.14$ & $4.330 \pm 2.01$ & $4.386 \pm 3.11$ \\
\hline Generation time $(G)^{1}$ & Days & $10.071 \pm 0.92$ & $11.400 \pm 0.46$ & $10.820 \pm 0.86$ & $10.081 \pm 1.36$ \\
\hline Life expectancy $\left(\mathrm{e}_{0}\right)$ & Days & $14.935 \pm 3.07 \mathrm{a}$ & $14.715 \pm 2.22 \mathrm{a}$ & $12.790 \pm 2.92 \mathrm{ab}$ & $7.320 \pm 1.51 b c$ \\
\hline
\end{tabular}

Means within a row followed by a different letter are significantly different (Fisher's protected least significant difference test: $P<$ $0.05)$.

Nymphs were removed daily after being counted.

${ }^{1}$ One cohort in the imidacloprid $10.3 \mathrm{ng} \mathrm{ml}^{-1}$ and two cohorts in the imidacloprid $16.9 \mathrm{ng} \mathrm{ml}^{-1}$ were excluded from the analysis because no nymphs were produced.

placed weekly and did not show any visible evidence of degradation, such as chlorosis, wilting, or disease. Such leaf degradation would reduce food quality and consequently impact the soybean aphid life table parameters obtained.

Although imidacloprid and thiamethoxam are very toxic to soybean aphid, the utility of seed treatments for soybean aphid management is still uncertain. Until recently, neonicotinoids have been used only as systemic insecticides in commercial soybean production. However, this could change due to inconsistent plant protection and limited economic return (McCornack \& Ragsdale, 2006).

The methodology reported in this investigation could be used to develop a baseline of susceptibility that can be used as a benchmark for subsequent resistance monitoring. Generating baseline susceptibility data is especially important for systemic insecticides. Seed treatments may provide an important management option that does not significantly impact natural enemies. However, the use of treated seeds should be carefully considered, because selection pressure may be higher, resistance may develop faster, and consistent benefit to soybean farmers is uncertain. Seed treatment may also increase selection pressure, because all developmental stages are exposed and as the insecticide degrades over time, the pest is exposed to sublethal concentrations (Taylor \& Georghiou, 1982). The sublethal effects estimated here may be useful in determining subtle changes in susceptibility that a $\mathrm{LC}_{50}$ may not detect. Furthermore, it may detect specific changes, such as reproductive parameter(s), survival, and longevity.

\section{Acknowledgments}

The authors thank Terence Spencer for his assistance in a development of bioassay methods. We also thank Dr. Eliseu J. G. Pereira and Laura A. Campbell for their assistance in calculating and analyzing the life table data.

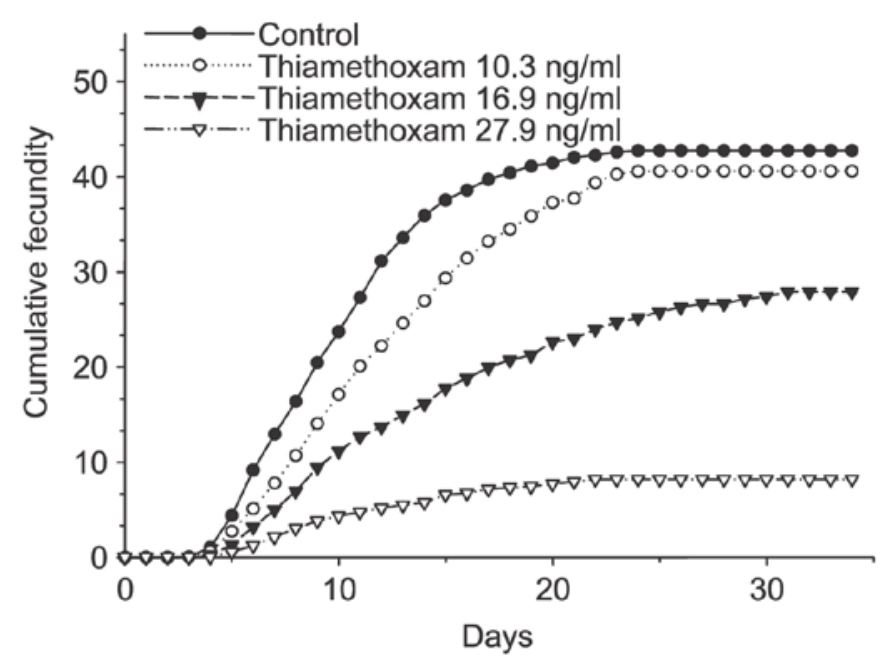

Figure 4. Cumulative fecundity of Aphis glycines reared on thiamethoxam concentrations corresponding to the $\mathrm{LC}_{25}$ $\left(10.3 \mathrm{ng} \mathrm{ml}^{-1}\right), \mathrm{LC}_{50}\left(16.9 \mathrm{ng} \mathrm{ml}^{-1}\right)$, and $\mathrm{LC}_{75}\left(27.9 \mathrm{ng} \mathrm{ml}^{-1}\right)$ compared to control.

\section{References}

Abbott WS (1925) A method of computing the effectiveness of an insecticide. Journal of Economic Entomology 18: $265-267$.

Albajes R, Lopez C \& Pons X (2003) Predatory fauna in cornfields and response to imidacloprid seed treatment. Journal of Economic Entomology 96: 1805-1813.

Devine GJ, Harling ZK, Scarr AW \& Devonshire AL (1996) Lethal and sublethal effects of imidacloprid on nicotine-tolerant Myzus nicotianae and Myzus persicae. Pesticide Science 48: 57-62.

Finney DJ (1971) Probit Analysis. Cambridge University Press, Cambridge, UK.

Galvan TL, Koch RL \& Hutchison WD (2005) Toxicity of commonly used insecticides in sweet corn and soybean to multicolored Asian lady beetle (Coleoptera: Coccinellidae). Journal of Economic Entomology 98: 780-789. 
Gotelli NJ (2001) A Primer of Ecology, 3rd edn. Sinauer Associates, Sunderland, MA, USA.

Heimpel GE, Ragsdale DW, Venette R, Hopper KR, O'Neil RJ et al. (2004) Prospects for importation biological control of the soybean aphid: Anticipating potential costs and benefits. Annals of the Entomological Society of America 97: 249-258.

Krauter PC, Sansone CG \& Heinz KM (2001) Assessment of Gaucho (R) seed treatment effects on beneficial insect abundance in sorghum. Southwestern Entomologist 26: 143-146.

LeOra Software (1987) POLO-PC. A user's Guide to Probit and Logit Analysis. Berkeley, CA, USA.

Li Y, Hill CB \& Hartman GL (2004) Effect of three resistant soybean genotypes on the fecundity, mortality, and maturation of soybean aphid (Homoptera: Aphididae). Journal of Economic Entomology 97: 1106-1111.

McCormack BP \& Ragsdale DW (2006) Efficacy of thiamethoxam to suppress soybean aphid populations in Minnesota soybean. Crop Management; doi: [DOI link].

McCormack BP, Ragsdale DW \& Venette RC (2004) Demography of soybean aphid (Homoptera: Aphididae) at summer temperatures. Journal of Economic Entomology 97: 854-861.

Mensah C, DiFonzo C, Nelson RL \& Wang DC (2005) Resistance to soybean aphid in early maturing soybean germplasm. Crop Science 45: 2228-2233.

Myers SW, Gratton C, Wolkowski RP, Hogg DB \& Wedberg JL (2005b) Effect of soil potassium availability on soybean aphid (Hemiptera: Aphididae) population dynamics and soybean yield. Journal of Economic Entomology 98: 113-120.

Myers SW, Hogg DB \& Wedberg JL (2005a) Determining the optimal timing of foliar insecticide applications for control of soybean aphid (Hemiptera: Aphididae) on soybean. Journal of Economic Entomology 98: 2006-2012.

Nauen R (1995) Behavior modifying effects of low systemic concentrations of imidacloprid on Myzus persicae with special reference to an antifeeding response. Pesticide Science 44: 145-153.

Nauen R \& Elbert A (1997) Apparent tolerance of a field-collected strain of Myzus nicotianae to imidacloprid due to strong antifeeding responses. Pesticide Science 49: 252-258.

Nauen R, Stumpf N \& Elbert A (2002) Toxicological and mechanistic studies on neonicotinoid cross resistance in Q-type Bemisia tabaci (Hemiptera: Aleyrodidae). Pest Management Science 58: 868-875.

Nault BA, Taylor AG, Urwiler M, Rabaey T \& Hutchison WD (2004) Neonicotinoid seed treatments for managing potato leafhopper infestations in snap bean. Crop Protection 23: 147-154.
Ostlie K (2001) Soybean Aphid Reduces Yields: Harvest Results from Insecticide Strip Trials. University of Minnesota, St. Paul, MN, USA. Available at http://0-www.soybeans. umn.edu.library.unl.edu/crop/insects/aphid/studyresults.htm

Prabhaker N, Castle S, Byrne F, Henneberry TJ \& Toscano NC (2006) Establishment of baseline susceptibility data to various insecticides for Homalodisca coagulata (Homoptera: Cicadellidae) by comparative bioassay techniques. Journal of Economic Entomology 99: 141-154.

Prabhaker N, Castle S, Henneberry TJ \& Toscano NC (2005) Assessment of cross-resistance potential to neonicotinoid insecticides in Bemisia tabaci (Hemiptera: Aleyrodidae). Bulletin of Entomological Research 95: 535-543.

Rutledge CE \& O'Neil RJ (2005) Orius insidiosus (Say) as a predator of the soybean aphid, Aphis glycines Matsumura. Biological Control 33: 56-64.

Rutledge CE \& O'Neil RJ (2006) Soybean plant stage and population growth of soybean aphid. Journal of Economic Entomology 99: 60-66.

Rutledge CE, O'Neil RJ, Fox TB \& Landis DA (2004) Soybean aphid predators and their use in integrated pest management. Annals of the Entomological Society of America 97: 240-248.

SAS Institute (2002) SAS User's Guide, Version 8.1. SAS Institute, Cary, NC, USA.

Satoh GT, Plapp FW \& Slosser JE (1995) Potential of juvenoid insect growth-regulators for managing cotton aphids (Homoptera: Aphididae). Journal of Economic Entomology 88: 254-258.

Stark JD \& Banks JE (2003) Population-level effects of pesticides and other toxicants on arthropods. Annual Review of Entomology 48: 505-519.

Taylor CE \& Georghiou GP (1982) Influence of pesticide persistence in evolution of resistance. Environmental Entomology 11: 746-750.

Tomizawa M \& Casida JE (2003) Selective toxicity of neonicotinoids attributable to specificity of insect and mammalian nicotinic receptors. Annual Review of Entomology 48: 339-364.

Tomizawa M \& Casida JE (2005) Neonicotinoid insecticide toxicology: mechanisms of selective action. Annual Review of Pharmacology and Toxicology 45: 247-268.

Venette RC \& Ragsdale DW (2004) Assessing the invasion by soybean aphid (Homoptera: Aphididae): where will it end? Annals of the Entomological Society of America 97: 219-226. 